\title{
ECONOMY
}

\section{ACTUAL ISSUES OF FINANCIAL STABILITY OF THE AGRICULTURAL SECTOR OF UZBEKISTAN}

\author{
Tashkent Financial Institute, Department of "Economics" \\ Doctoral student Bafoyev Otabek
}

DOI: https://doi.org/10.31435/rsglobal_wos/31082019/6654

\section{ARTICLE INFO}

Received: 17 June 2019

Accepted: 09 August 2019

Published: 31 August 2019

\section{KEYWORDS}

clusters, agro-industrial sector, agricultural products efficiency, production, average costs, fixed costs, variable costs, commercial production costs, cash expenses, calculation of production costs, direct and indirect costs, total costs, social contributions, material costs, depreciation of fixed assets, agricultural production efficiency.

\begin{abstract}
This article examines the prospects for increasing the competitiveness of the agro-industrial complex of the Republic of Uzbekistan through the formation and development of clusters as an innovative type of production management, outlines the main problems and the current state of the domestic agro-industrial sector, which forms national food security, directions and mechanism for the development of factors aimed at creating conditions for sustainable growth of the country's economy. At present, characterized by the global trend of growing global competition, the problem of finding new factors that can ensure the growth of national competitiveness and sustainable development of the state's economy arises, and this makes this article relevant.

One of the means of updating the production management system to solve this problem is the cluster approach, which can be effectively implemented, when will be taken into account the specific conditions of certain areas of economic activity.
\end{abstract}

Citation: Bafoyev Otabek. (2019) Actual Issues of Financial Stability of the Agricultural Sector of Uzbekistan. International Academy Journal Web of Scholar. 8(38), Vol.1. doi: 10.31435/rsglobal_wos/31082019/6654

Copyright: (C) 2019 Bafoyev Otabek. This is an open-access article distributed under the terms of the Creative Commons Attribution License (CC BY). The use, distribution or reproduction in other forums is permitted, provided the original author(s) or licensor are credited and that the original publication in this journal is cited, in accordance with accepted academic practice. No use, distribution or reproduction is permitted which does not comply with these terms.

The agro-industrial complex of Uzbekistan occupies a special place, since it forms the foundations of the country's economic security and ensures the availability of food and raw material resources of the state's external and internal market. For the effective functioning of the agro-industrial complex of the Republic of Uzbekistan, it is necessary to create rational conditions for the development of industrial and economic relations that contribute to the achievement of high final results of its activities.

Therefore, increasing the competitiveness of the agro-industrial complex of Uzbekistan through the creation and development of clusters is the most important national task. The world economic experience of the last decade has confirmed the effectiveness of such a direction in improving production management in various economic fields has proved that with the help of clusters a synergistic effect can be achieved, which the agro-industrial complex of Uzbekistan needs during the global economic crisis. The issue of creating clusters as a way to increase competitiveness has been given the attention of many famous scientists. A. Marshall can be considered the founder of this theory. Clusters theory issues are considered in more detail in the works of M. Porter [6].

The seasonal nature of labor in agriculture gives rise to an advance payment system during the year. With such a system, it is practically impossible to build a set of stimulating tools for working in a team, as required by the theory of organizational behavior. In addition, the results of labor in agricultural production are greatly influenced by the agro climatic potential and the amount of those financial resources that agricultural producers invest in cultivating the land. If such funds are needed a lot, then the reserve for the growth of wages in agricultural production does not remain, as Table 1 shows. 
Table 1. Basic indicators of the agro-climatic potential of different countries in 20013-2018[9]

\begin{tabular}{|c|c|c|c|c|}
\hline Country & Population & $\begin{array}{c}\text { Area, } \\
\text { for 1 person, ha }\end{array}$ & $\begin{array}{c}\text { Land } \\
\text { Biological } \\
\text { Productivity } \\
\text { Index }\end{array}$ & $\begin{array}{c}\text { Energy costs } \\
\mathbf{j} / \text { ha }\end{array}$ \\
\hline & $\begin{array}{c}\text { number } \\
\text { million } \\
\text { people }\end{array}$ & & & \\
\hline USA & 250 & 0,27 & 1,70 & 0,54 \\
\hline CHINA & 1150 & 1,2 & 0,36 & 0,45 \\
\hline ITALY & 57,2 & 1,9 & 0,30 & 0,16 \\
\hline RUSSIAN & 147 & 0,09 & 1,42 & 0,15 \\
\hline UZBEKISTAN & 15,6 & 0,005 & 1,39 & 0,10 \\
\hline
\end{tabular}

As can be seen from the data in Table 1, Uzbekistan needs to make much more efforts in gaining returns from land than other countries in the world. As a result, this cannot but affect the availability of reserves of Uzbek agricultural producers for the accelerated growth in them of those sources that could go to increase wages [13].

Agricultural production differs from other areas of economic activity. Agricultural production have an "ideal" life cycle, i.e. is in constant demand, but these products enter the food market mainly only after the processing process, where consumers often look for new items as well as the usual product. However, firstly, agricultural producers do not have direct contact with consumers and can little influence them on the change in their demand, and secondly, in their production they are tied to the natural and climatic conditions and the special characteristics of land fertility [12]. In addition, "force majeure" circumstances can have a significant impact on the results of labor of agricultural producers. Naturally, all these circumstances lead to high costs and do not leave sources for agricultural producers to influence their workers through an increase in wages. As a result, wages in agriculture in Uzbekistan remain the lowest compared to wages in other sectors of the economy. When agricultural production prevails in the households of the population $(95.5 \%$ in 2017), it is difficult to divide the income from its results between farm members, and even more so to differentiate among individual workers so that members of the same family do not have any grievances [7]. Remuneration in such farms usually comes in the form of financial results as total family income. It also serves as an obstacle to using the provisions of organizational behavior in the agricultural production system. Due to the lack of free financial resources from agricultural producers in Uzbekistan, many innovations in this area come in the form of implementing state projects [8]. The family business is booming in farms, in the bowels of which it is difficult to build remuneration in accordance with the concept of organizational behavior. In its economic nature, the presence of such a number of small farms is a step backward, since human experience in the field of agricultural production has proved that the functioning of small farms on land is low cost-effective. Therefore, society in the field of any type of production is everywhere developing towards its enlargement (individual - family - clan, collective - state, interstate unions - international associations). Proof of this process can serve as dominance in the international economy of multinational companies and corporations, financial and industrial groups, which are increasingly gaining strength and influence. From this perspective, the US experience is also interesting, where the creation of conditions for the unification of farms is considered as state policy, as a source of achieving national food security, and where the initial experience of targeting the small-scale farming sector was not justified. With the development of small forms of land use and in the current competitive environment, farming in the United States has become unprofitable and ultimately not promising. Therefore, now the US agricultural policy is aimed at ensuring that the share of the largest agricultural enterprises in the USA in the near future reaches $80 \%$ in the output of agricultural products. To this end, the US budget provides assistance in combining small farms in the amount of $1.2 \%$ of the national budget [14]. Agricultural production and the food market are not self-regulatory areas of economic activity. The fact is that the demand for food in general and in general is characterized by low elasticity, making this sector of the economy very conservative. Therefore, the introduction of innovations in this area is weakly correlated with the possibility of building additional payments to agricultural workers, which requires the search for other measures of labor productivity growth, where the total wage depends on the volume of products sold. Therefore, a gain on a scale can have a greater impact on the growth of incomes of the population engaged in agricultural production. All of the above features of the organization of innovative management in agricultural production leave him only one way - 
the development of integration and cooperative processes, including the creation of clusters and socioentrepreneurial companies, the formation on the same territory of complexes of enterprises connected by the unity of the technological process in food production, including elements of market infrastructure in the form of service procurement centers, etc.

From this point of view, the creation of clusters allows not only to enlarge production, but also to strengthen the processes of corporatization as a way to create corporate governance in national agro-industrial production. From this point of view, the creation of clusters allows not only to enlarge production, but also to strengthen the processes of corporatization as a way to create corporate governance in national agro-industrial production.

The cluster concept is interesting in that it presents a new point of view on the development of the national economy, the economy of a region or a separate territory, and also reveals new roles for companies, governments (or local governments) and other organizations that seek to increase the competitiveness of the economy of a country or region as a source for the subsequent increase in the standard of living of the rural population. Given the fact that the basis of a country's competitiveness in the world market is the growth of labor productivity of leading companies due to the implementation of unification processes carried out with the help of the state. Moreover, productivity growth, in our opinion, is carried out in this case as a complex concept, including the following components aimed at achieving a gain on the scales indicated in.

Table 2. Components of company productivity growth [8]

\begin{tabular}{|l|l|}
\hline $\begin{array}{l}\text { Cluster Performance } \\
\text { Components }\end{array}$ & Content of Component \\
\hline Efficiency of production & modernization, labor productivity, human resource development \\
\hline Quality of product & quality assurance system for products through mutual control \\
\hline $\begin{array}{l}\text { novelty of products and } \\
\text { technologies }\end{array}$ & $\begin{array}{l}\text { system for developing and introducing innovations through } \\
\text { organization }\end{array}$ \\
\hline
\end{tabular}

Only a combination of these three components, as shown in Table 2, [8] determines the potential competitiveness of the cluster in the modern economic space. In fact, national companies must satisfy these requirements, which are necessary for adapting to competition in the foreign and domestic market. This can be achieved most often by combining the unidirectional efforts of many business entities interconnected by economic relations in one market. In fact, in order to achieve success in international markets, it is necessary to specialize in clusters in those industries that provide high performance in the aforementioned complex sense. Thus, the issue of increasing labor productivity in the agricultural sector of Uzbekistan is steadily reduced to the fact that all sectors and firms cannot be competitive in the international market. Only some of them will be able to find their own niche and develop it, and it is necessary that all agricultural production in Uzbekistan become highly competitive, that is, we are talking about a specific segment of the economy and those industries in which world-competitive products can be created and improved. Long-term scientific studies conducted by economists on the materials of developed and developing countries confirm the importance of the integrated development of mutually complementary types and areas of activity in the cluster, as mentioned above. According to the results of these studies, clusters take various forms depending on their depth and complexity, but for the most part they include:

- finished product companies or service companies;

- suppliers of specialized factors of production, components, machines, as well as services;

- financial institutions;

- firms in related industries

In addition, clusters can often combine:

- firms working with distribution channels and consumers;

- manufacturers of raw materials and by-products;

- specialized infrastructure providers;

- government and other organizations providing education and special training, conducting specialized research;

- agencies setting standards and carrying out marketing research;

- Government bodies (including local governments) that have a significant impact on the functioning of the cluster and are considered as part of it.

Therefore, it is necessary to invest in the concept of cluster development the creation of such a level of cooperation in the production of any particular product that will not be inferior in quality to the best foreign analogues when other enterprises specializing in the production of related products 
included in the system are from the very beginning to the end of the technological process will act as a single mechanism at any stage that guarantees the provision of high quality production. [11] At the same time, we are not talking about concentrating production in one hand, but talking about involving medium and small producers in the production process, which are the basis for the formation of the final product. This ensures the development of existing and the creation of new industries, not large in size, but the latest in the quality parameters of the use of technology in small and medium-sized enterprises that form the middle class in the country.

Yet there are a number of conditions that can both contribute to and hinder the development of clusters in Uzbekistan. Experts attribute the following to positive conditions: the existence of technological and scientific infrastructures, psychological readiness for cooperation.

The latter fact makes us pay attention to the question of the scale of regional development management. Therefore, it is possible to talk about the successful implementation of projects on special cluster stimulation only if there is a certain regional strategy. To do this, the local administration must prove the following growth factors to cluster members:

- In competition, cooperation is more effective than individual actions;

- The location of the clusters requires careful justification and selection;

- An active cluster strategy may become the most attractive for foreign investors;

- In the framework of cluster development, entrepreneurs can get more help from scientific organizations;

- clustering contributes to the centralized acquisition of market information with high speed.

At present, other factors, such as:

- Low quality of feedstock;

- A high degree of moral and physical depreciation of fixed assets,

- Lack of working capital and investment;

- Low qualification of specialists;

- The lack of a quality management system in agricultural production;

- Uncontrolled pricing in agricultural intermediaries;

- High cost of production or purchase of containers;

- Lack of raw materials for industrial processing due to the difficulties of collecting it on small farms;

- Price dictates of processing enterprises in relation to producers of agricultural raw materials; innovation in agricultural production.

From these positions, Uzbekistan needs:

- expand leasing of new agricultural machinery;

- contribute to the development of rural credit partnerships;

- expand the system of use of grain receipts and create conditions for their use as collateral in peasant (farmer) farms;

- improve the insurance system for agricultural activities, especially agricultural production;

- create tools to attract the entire population to development.

In this case, the basic principles of the formation of the cluster functioning mechanism should be ensuring self-development, self-financing, permanent profitability and self-sufficiency [4]. For this, in Uzbekistan it is necessary to develop ways of participation of the population living in the cluster territory in the integration processes by expanding the corporatization system.

Then the assessment of the cluster's property potential can be taken into account not only in terms of the amount of land and real estate to be connected, but also in terms of rented or being on conservation of the first installments of future cluster members. To do this, Uzbekistan requires:

- further improvement of the regulatory and legislative framework that expands the access of the population to the use of financial instruments as a source of participation in corporatization;

- development of law enforcement mechanisms and a system of insurance of the rights of shareholders participating in the agro-industrial business, even without land ownership;

- development of a set of measures aimed at a more simplified version of the participation of the entire population in the processes of corporatization;

- the presence of more specialized institutions capable of carrying out trust operations by order of the population;

- the creation of a system of control over the use of funds of the population for its intended purpose.

At the same time, the mechanism of cluster functioning should include the possibility of assessing[9]: 
- the growth of investment funds through the consolidation of public finances;

- improving the conditions for investing free funds of the population in the system of economic activities in the cluster;

- ways of developing civilized methods of combating competition;

- the potential for expanding methods of promoting a product on the market;

- the presence of additional sources of innovation;

- developing opportunities to overcome barriers to entry into new markets;

- the search for extension methods to overcome all types of risk.

Particular attention when creating a mechanism for the functioning of the cluster should be given to the development of prospects for training and retraining of personnel, attracting scientists and scientific organizations to search for innovations on its territory [5].

When creating a cluster, it must be borne in mind that it can be effective if the products produced on its territory can be:

- Subject to differentiation and diversification;

-reached on a scale;

-Achieved leadership in low costs;

-develop the potential for entering new markets;

- carried out aggressive promotion of goods on the market.

For sustainable development of the agro-industrial sphere of the economy of Uzbekistan, innovative management methods are needed that can develop integration processes among enterprises in this sphere, especially among small businesses, which should be stimulated by the state. The creation of innovative forms of management in the agro-industrial complex of Uzbekistan should be aimed at diversifying the activities of its enterprises as a way to create opportunities to engage in the production of a new product or other type of activity that is related to the main one, previously not typical for them, but allowing to introduce structural transformations not only into your work, but also in the range of their products. To this end, the state should help the entities of the agri-food market of Uzbekistan with all the opportunities available to it in the form of stimulating the processes of diversification of production as a way to develop intersectoral relations in the agro-industrial sphere of the state economy.

Together, all of the above allows us to draw the following conclusions:

- The creation of clusters only with the help of state assets does not always fully justify itself. However, the country has not yet created a full-fledged mechanism for attracting private entrepreneurs to their participation in the cluster development of the country. This requires the development of appropriate financial and tax benefits for entrepreneurs participating in the functioning of clusters, aimed at developing entrepreneurial motivation for their more active participation in cluster processes and creating such a mechanism for the functioning of clusters in which the business environment could see its benefits from this participation.

- The main goal of creating clusters on the territory of the Republic of Uzbekistan should be the potential for innovative development as the core of the cluster, around which all its other elements should be formed, including personnel training, the participation of science and ways to accelerate the information support of all entities included in each cluster process.

\section{REFERENCES}

1. Aker, J. C. (2011), Dial "A" for agriculture: a review of information and communication technologies for agricultural extension in developing countries. Agricultural Economics, 42: 631-647. USA

2. Anaeto F.C., Asiabaka C.C., Nnadi F.N, Ajaero J.O., Ugwoke F.O., Ukpongson M.U \&Onweagba, A.E. (2012). The role of extension officers and extension services in the development of agriculture in Nigeria. Wudpecker, Journal of Agriculture Research, 1(6):180-185. Nigeria.

3. Archer, N. P., Ghasemzadeh, F., Brooking, A., Board, P., Jones, S. (1998). The Predictive Potential of Intellectual Capital, Volume 16, Issue 1-3.

4. Баутин В.М. Понятие “инновация" как экономическая категория // Развитие инновационной деятельности в АПК: Материалы международной научно-практической конференции. - М.: ФГНУ «Росинформагротех». 2003. - 251-253 с.

5. Baller. S., Dutta S., \& Lanvin,B. [Eds].(2017).The Global Information Technology Report 2016: Innovating in the Digital Economy: Geneva: World Economic Forum, 307 p.

6. Birner R, Davis K, Pender J, Nikoniya E, Anandajayasekeram P, Ekboir J, Mbabu A, Spielman D, Benin S. (2006). From best practice to best fit: A framework for analyzing agricultural advisory services wordwide. Development Strategy and Governance Division, Discussion p.39, IFPRI, Washington, DC. 
7. Birner R, Anderson O (2007). How to make agricultural extension demand driven? The case of India's agricultural extension policy. IFPRI Discussion Paper 00729, Development Strategy and Governance Division, IFPRI, Washington, DC.

8. Knickel, K., Brunori, G., Rand, S., \&Proost, J. (2009). Towards a better conceptual framework for innovation processes in agriculture and rural development: From linear models to systemic approaches. The Journal of Agricultural Education and Extension, 15, 131-146

9. Knierim, A., Labarthe, P., Laurent, C., Prager, K., Kania, J., Madureira, L., \&Ndah, T. H. (2017). Pluralism of agricultural advisory service providers-Facts and insights from Europe. Journal of RuralStudies, 55, 45-58.

10. Kaplan, R. S., Norton, D. P. (1996). The Balanced Scorecard. Boston: Harvard Business School Press, P. $75-85$.

11. Карташов Е.Ф. Модернизация сельскохозяйственного производства на основе трансфера инновационных технологий. ФГБОУ ВПО «Мордовский государственный университет имени Н.П. Огарева». Научный журнал «Фундаментальные исследования». №9. 2013 г.

12. Перушкевич И.П. Методические аспекты оценки инновационной активности сельскохозяйственных организаций //Вестник Алтайского государственного аграрного университета. 2013. № 7. С.138-141.

13. Sveiby, K. E. (1997). The Intangible Assets Monitor. Journal of Human Resource Costing \&Accounting, Vol. 2, Issue 1, P. 73-97.

14. Stewart, T. A. (1998). Intellectual Capital: The New Wealth of Organizations. N.Y.-L.: Doubleday. Currency, $288 \mathrm{p}$. 